\title{
Utilization of discarded foundry sand (DFS) and inorganic waste from cellulose and paper industry for the manufacture of glass-ceramic materials
}

\author{
(Utilização de areia descartada de fundição (ADF) \\ e resíduos inorgânicos da indústria de papel e celulose \\ para a produção de materiais vitrocerâmicos)
}

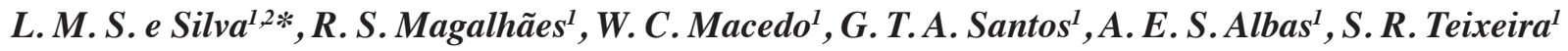 \\ ${ }^{1}$ Universidade Estadual Paulista, Faculdade de Ciências e Tecnologia, Departamento de Física, \\ 19060-900, Presidente Prudente, SP, Brazil \\ ${ }^{2}$ Universidade do Oeste Paulista, Faculdade de Engenharia e Arquitetura, Presidente Prudente, SP, Brazil
}

\begin{abstract}
Recycling has been pointed out as an alternative to the disposal of waste materials in industrial landfills. In the present study, the transformation of residues (discarded foundry sand - DFS, grits, and lime mud) in glass-ceramic materials is shown. The glasses were obtained by the melting/cooling method. The precursor materials, glasses, and glass-ceramics were characterized by X-ray diffraction (XRD), X-ray fluorescence (XRF), and differential scanning calorimetry/thermal gravimetric analysis (DSC/TGA). The glassy materials were milled, pelleted, and thermally treated at the crystallization temperatures given by DSC data to obtain the glass-ceramics $\left(885,961\right.$, and $\left.1090{ }^{\circ} \mathrm{C}\right)$. The main formed phases were cristobalite, $\alpha$-wollastonite (parawollastonite), and $\beta$-wollastonite (pseudowollastonite). The glass-ceramics showed very low water absorption and apparent porosity $(0.26$ to $0.88 \mathrm{wt} \%$ and 0.66 to $1.77 \mathrm{vol} \%$, respectively). The results confirmed that the studied residues can be used as raw materials for the manufacture of vitreous and glass-ceramic materials.
\end{abstract}

Keywords: DFS, grits, lime mud, glass, glass-ceramic.

Resumo

A reciclagem tem sido apontada como alternativa ao descarte de resíduos em aterros industriais. No presente trabalho é mostrada a transformação de resíduos (areia descartada de fundição - ADF, grits e lama de cal) em materiais vitrocerâmicos. Os vidros foram obtidos pelo método de fusão/resfriamento. Os materiais precursores, compostos vítreos e vitrocerâmicos foram caracterizados pelas técnicas de difração de raios $X(D R X)$, fluorescência de raios X (FRX) e calorimetria exploratória diferencial/análise termogravimétrica (CED/ATG). Os materiais vítreos foram moídos, pastilhados e tratados termicamente nas temperaturas de cristalização obtidas por CED para preparar os materiais vitrocerâmicos $\left(885,961\right.$ e $\left.1090^{\circ} \mathrm{C}\right)$. As fases obtidas foram cristobalita, $\alpha$-wolastonita (parawolastonita) e $\beta$-wolastonita (pseudowolastonita). As vitrocerâmicas apresentaram baixa absorção de água e porosidade aparente $(0,26$ até 0,88 wt\% e 0,66 até 1,77 vol\%, respectivamente). Os resultados confirmaram que os resíduos estudados podem ser utilizados como matéria-prima na fabricação de materiais vítreos e vitrocerâmicos.

Palavras-chave: $A D F$, grits, lama de cal, vidros, vitrocerâmicos.

\section{INTRODUCTION}

The industrialization process is essential for improving the population's quality of life and for the economic strengthening of a country. However, there is a lack of synchronization between industrialization and environmental protection. Moreover, the quantitative and qualitative increase of industrialized products generates a large amount of waste -

*leilasotocorno@gmail.com

Dhttps://orcid.org/0000-0001-7249-2284 solid, liquid, and gaseous. Unfortunately, most of this waste has been incorrectly disposed of in the environment, causing adverse impacts on natural resources and different biomes. Thus, it is urgent to search for alternatives that can minimize, reuse, and/or recycle the various solid wastes generated, especially industrial ones, in order to mitigate the negative impacts from their incorrect disposal. Recently, solid wastes from foundry and cellulose/paper companies have gained attention due to their importance for the Brazilian economy as significant human and financial resources are employed in these sectors. According to the data from the Brazilian Foundry Association, Brazil generates more than 
2.8 million ton per year of discarded foundry sand (DFS), which correspond to over $70 \%$ of solid waste generated in this sector [1-3]. In the case of cellulose waste, CENIBRA Institute (Celulose Nipo-Brasileira) reported that, on average, each ton of cellulose produced generates $200 \mathrm{~kg}$ of solid waste, half of which is inorganic solid waste (dregs, grits, and lime mud) [4].

Some researches on waste from foundry industry have focused on DFSs due to their high volume ( $86 \%$ of generated waste [5]) and also to the various applications, such as utilization as aggregate in the manufacture of Portland cement concrete [6], and road paving [7, 8]. Some works report the use of foundry waste, either without separation or mixed with other residues [9-14]. The number of published papers on the use of DFS in cement and concrete artifacts is extensive; however, few studies have focused on the use of DFS in the production of glass or glass-ceramic materials [2]. Martin et al. [13] studied the fabrication of soda-lime glass with partial replacement of sand by DFS as a source of silica. They concluded that a $25 \%$ replacement of silica by DFS is possible and resulted in a green glass due to the presence of iron. Brazil has turned into one of the most important countries for paper and cellulose production. In 2012, the country was the world's $4^{\text {th }}$ largest producer of cellulose, as well as the $11^{\text {th }}$ largest producer of cellulose and paper [15]. Additionally, Bacha [16] mentioned that since 2016 Brazil is the $2^{\text {nd }}$ greatest world producer of cellulose, allocating two-thirds of its production to the international market (total production of 18.8 million ton in 2016 and 19.5 million ton in 2017). Belotte et al. [17] have reported extensive work about the recovery of wastes from cellulose manufacturing, and several applications of these residues were reported: for soil acidification or as a fertilizer, soil recovery in mining areas, asphalt pavement aggregates, mortar aggregates, and in the cement and ceramic industries. For proper waste management, it is essential to know the origin of alkaline solid materials from the chemical procedures. The grits and lime mud used in the present study for the production of glass-ceramic materials were mainly composed of $\mathrm{CaCO}_{3}$ and some other important impurities.

Glass-ceramics are materials that have one or more crystalline phases dispersed in a glass phase. They are produced by controlling the crystallization in isothermal and non-isothermal methods. The incorporation of solid waste in glassy and glass-ceramic materials has been studied by different researchers in order to obtain economically viable and environmentally safe compounds. For the chosen composition, many silicate glasses could be prepared to provide different crystalline phases during glass crystallization. These different phases present a large variety of applications. Wollastonite $\left(\mathrm{CaSiO}_{3}\right)$ based glass-ceramic, such as Neopariés, is widely commercially available. This glass-ceramic material is commonly used in civil engineering as tiles for structures in general (floors, walls, and columns) due to its interesting mechanical properties [18]. Since DFS, grits, dregs, and lime mud wastes are classified by the Brazilian ABNT NBR 10004:2004 standard as class IIA solid wastes (non-hazardous and non-inert), they can simply be sent to industrial landfills [19]. However, it becomes essential, nowadays, to provide sustainable alternatives for better use of such wastes. Their incorrect disposal can generate environmental problems and also contribute to the demand for virgin natural resources. Therefore, this study aims to manufacture glass and/or glass-ceramic materials as alternative reuse for these residues.

\section{MATERIALS AND METHODS}

Characterization of precursor materials: the precursor materials were discarded foundry sand (DFS) and inorganic solid wastes from the cellulose and paper industry grits and lime mud. DFS was obtained from a foundry company located in the city of Presidente Prudente, São Paulo (Brazil), while cellulose waste was obtained from a company located in Três Lagoas, Mato Grosso do Sul (Brazil). The characterization of the homogenized portions of each material was performed by granulometric analysis, in which $500 \mathrm{~g}$ of each sample was kept in a stove $\left(60^{\circ} \mathrm{C}\right)$ for $24 \mathrm{~h}$ and sieved $(4,8,16,30,50,100$, and 200 mesh) in a mechanical shaker (Solotest). The loss on ignition values at $1000{ }^{\circ} \mathrm{C}$ for a portion of the residues $(\sim 1 \mathrm{~g})$ were determined by weighing on a semi-analytical balance. After that, the resulting residues were milled and analyzed by X-ray fluorescence spectroscopy (XRF, Axios Max, Malvern Panalytical) to determine its chemical compositions using an $\mathrm{Rh}$ anode as the excitation source. The scans were performed in the energy range from $\mathrm{Na}$ to $\mathrm{U}$, in qualitativequantitative mode at room temperature in the vacuum (for glasses A and B). X-ray diffraction (XRD) analysis was carried out in a diffractometer (XRD 6000, Shimadzu) at room temperature with $\mathrm{CuK} \alpha 1(\lambda=1.5406 \AA)$ radiation, divergence slits, and $1^{\circ}$ reception, in the continuous scan, $40 \mathrm{kV}$ voltage, $30 \mathrm{~mA}$ current, $2 \% \mathrm{~min}$ scan speed, and $2 \theta$ angular range from $10^{\circ}$ to $80^{\circ}$. The diffraction patterns were identified by powder diffraction files (PDF) from the Joint Committee on Powder Diffraction Standards (JCPDS-ICDD) database. The samples $(\sim 10 \mathrm{mg})$ submitted to simultaneous thermogravimetry/differential scanning calorimetry (TGA/ DSC) were performed in a thermal analyzer (SDT Q600, TA Instr.) with alumina crucibles, a heating rate of $10{ }^{\circ} \mathrm{C} / \mathrm{min}$ from 35 to $1400{ }^{\circ} \mathrm{C}$, and a synthetic airflow of $100 \mathrm{~mL} / \mathrm{min}$. The maximum and/or minimum positions of the thermal processes were determined using an equipment software (Universal Analysis 2000, TA Instr.).

Preparation and characterization of glass and glassceramic materials: it is important to emphasize that the cellulose waste was previously treated at $1000{ }^{\circ} \mathrm{C}$ for $1 \mathrm{~h}$ in a low-temperature oven (mod. 3000, EDG), before the preparation of the glass and glass-ceramic materials, to release gases $\left(\mathrm{H}_{2} \mathrm{O}, \mathrm{CO}_{2}, \mathrm{O}_{2}\right.$, and $\left.\mathrm{SO}_{2}\right)$ that may be harmful to the high-temperature oven (mod. 170, Servifor). Glass materials: the formulations of the precursors were calculated according to the phase diagram of the ternary system $\mathrm{SiO}_{2}-$ $\mathrm{Al}_{2} \mathrm{O}_{3}-\mathrm{CaO}$ [18] aiming to obtain the crystalline phases 
of each glass-ceramic material. DFS contributed to silica and the cellulose residues (grits and lime mud) to calcium oxide. Sodium oxide (Sigma-Aldrich, 98\%) was added as a flux (in order to lower the melting point), and alumina (Sigma-Aldrich, 99\%) was used to favor the formation of calcium silicates. The glass materials (frits) were prepared in alumina crucibles using the combination of DFS and two inorganic cellulose residues (grits and lime mud), forming two compositions (Table I), which were calculated from the results of the XRF analysis of the precursor materials. According to the chemical compositions of the precursor materials and mixtures, the glasses were obtained at around $1450{ }^{\circ} \mathrm{C}$ for $30 \mathrm{~min}$ through the traditional method (melting and cooling). The molten material was poured into the water at room temperature. Melting temperatures were calculated according to the Chengyu-Ying model for silica glasses [20]. Finally, the glasses were characterized by $\mathrm{XRD}, \mathrm{XRF}$, and thermal analysis to determine the chemical composition, glass phase, and crystallization temperatures, respectively. Glass-ceramic materials: they were obtained from the crystallization (nucleation + grain growth) of each frit. The frits (glasses A and B) were ground in a mortar and sieved on a 170 mesh $(0.088 \mathrm{~mm})$ sieve to reduce the effect of particle size on the thermal reactions of each glass. A sample of the fraction smaller than 170 mesh was studied by thermal analysis in order to determine the crystallization temperatures of each composition. The remaining sample was homogenized in an agate mortar with one drop of glycerol $\left(\mathrm{C}_{3} \mathrm{H}_{8} \mathrm{O}_{3}\right.$, Sigma-Aldrich, 99.5\%), and pelleted in a $30 \mathrm{kN}$ uniaxial press (Shimadzu). After determining each crystallization temperature, the pellets were heated at $10^{\circ} \mathrm{C} / \mathrm{min}$ to the treatment temperature (indicated by the thermal analysis). The thermal treatment occurred at temperatures above the crystallization peak temperature for $1 \mathrm{~h}$ to each pellet. Finally,

Table I - Compositions of the two mixtures to prepare the frits. [Tabela I - Composições das duas misturas para preparação das fritas.]

\begin{tabular}{cc}
\hline Glass & Composition (wt $\%)$ \\
\hline$A$ & $70 \%$ DFS-20\% grits-5\% $\mathrm{Na}_{2} \mathrm{O}-5 \% \mathrm{Al}_{2} \mathrm{O}_{3}$ \\
B & $70 \%$ DFS-20\% lime mud-5\% $\mathrm{Na}_{2} \mathrm{O}-5 \% \mathrm{Al}_{2} \mathrm{O}_{3}$ \\
\hline
\end{tabular}

the glass-ceramic pellets were characterized by XRD and Archimedes method for determination of water absorption, apparent porosity, and apparent specific gravity.

\section{RESULTS AND DISCUSSION}

Table II shows the results of particle size analysis of discarded foundry sand (DFS), grits, and lime mud. It was observed that $53.7 \%$ of the DFS particles had a grain size between 0.149 and $0.297 \mathrm{~mm}$. For cellulose residues, the lime mud presented smaller granulometry (thinner material), which can result in higher moisture adsorption and lower temperatures in the observed thermal events [21], when compared to grits. Smaller particles are more reactive due to their larger surface area.

Table III presents the results of the semi-quantitative chemical analysis of solid wastes by XRF spectrometry. The amount of $\mathrm{SiO}_{2}$ was higher in the DFS sample, over $95 \%$. DFS showed potential for glass production since silicon dioxide is one of the main vitreous network formers. It is also possible to observe the presence of $\mathrm{Fe}_{2} \mathrm{O}_{3}$, a colorant of glassy materials [22]. Cellulose residues showed similarities regarding the chemical composition. Both compounds presented a high $\mathrm{CaO}$ concentration $(\geq 55 \%)$. $\mathrm{CaO}$ acts as a vitreous network modifier, as it is a bivalent cation and enters the network to form ionic bonds with non-bridging oxygens [23]. These wastes are used as a calcium source to form calcium silicate, as wollastonite. Similar percentage values of minority components $\left(\mathrm{P}_{2} \mathrm{O}_{5}, \mathrm{Na}_{2} \mathrm{O}, \mathrm{MgO}\right.$, and $\left.\mathrm{SrO}\right)$ present in the residues were observed. Furthermore, there was no evidence of heavy metals with high toxicity as $\mathrm{Hg}$ or $\mathrm{Pb}$ in the compounds by XRF. The LOI (loss on ignition) for both residues presented values above $40 \%$. These minority components act as fluxes (lowering the melting temperature), stabilizers of the glass, and/or a vitrifying agent (glass network formers) [24].

To identify the crystalline phases present in the precursors, XRD characterization of the homogenized powders was performed. The diffractogram of the DFS sample (Fig. 1) showed a single-phase, referring to $\alpha$-quartz $\left(\mathrm{SiO}_{2}\right)$, crystalline phase with hexagonal structure (PDF 83-2469). This result corroborated the data obtained by XRF. Silicon

Table II - Results of particle size analysis (retained fraction) of precursor wastes.

[Tabela II - Resultados da análise do tamanho de partículas (fração retida) dos resíduos precursores.]

\begin{tabular}{ccccc}
\hline Sieve (mesh) & Opening $(\mathrm{mm})$ & DFS $(\mathrm{wt} \%)$ & Grits $(\mathrm{wt} \%)$ & Lime mud $(\mathrm{wt} \%)$ \\
\hline 4 & 4.760 & 9.42 & 0.00 & 0.06 \\
8 & 2.380 & 4.91 & 2.10 & 0.66 \\
16 & 1.190 & 1.34 & 25.30 & 0.64 \\
30 & 0.590 & 0.62 & 37.90 & 0.53 \\
50 & 0.297 & 24.90 & 11.90 & 0.98 \\
100 & 0.149 & 53.70 & 9.07 & 10.90 \\
200 & 0.074 & 2.54 & 8.89 & 46.10 \\
$<200$ & $<0.074$ & 2.57 & 4.83 & 40.20 \\
\hline
\end{tabular}


Table III - Results of semi-quantitative chemical analysis (wt\%) of precursor wastes by XRF spectrometry.

[Tabela III - Resultados da análise química semiquantitativa (\% em massa) dos resíduos precursores por espectroscopia de FRX.]

\begin{tabular}{cccc}
\hline Oxide & DFS & Grits & Lime mud \\
\hline $\mathrm{CaO}$ & 0.20 & 55.80 & 55.00 \\
$\mathrm{SiO}_{2}$ & 95.40 & 0.90 & 0.20 \\
$\mathrm{Al}_{2} \mathrm{O}_{3}$ & 0.60 & 0.70 & 0.10 \\
$\mathrm{P}_{2} \mathrm{O}_{5}$ & $<0.10$ & 0.60 & 0.50 \\
$\mathrm{Na}_{2} \mathrm{O}$ & 0.10 & 0.60 & 0.50 \\
$\mathrm{MgO}$ & 0.10 & 0.30 & 0.30 \\
$\mathrm{SrO}$ & - & 0.30 & 0.30 \\
$\mathrm{SO}_{3}$ & $<0.10$ & 0.20 & 0.10 \\
$\mathrm{Fe}_{2} \mathrm{O}_{3}$ & 1.00 & 0.10 & 0.10 \\
$\mathrm{~K}_{2} \mathrm{O}$ & 0.10 & $<0.10$ & $<0.10$ \\
$\mathrm{TiO}_{2}$ & $<0.10$ & - & - \\
$\mathrm{ZrO}_{2}$ & $<0.10$ & - & - \\
$\mathrm{LOI}^{2}$ & 2.50 & 40.40 & 43.10 \\
\hline
\end{tabular}

LOI: loss on ignition.

oxide, quartz, is a network former and is extensively used for the production of glassy and glass-ceramic materials for several applications $[25,26]$. Fig. 2 shows the diffractogram of each inorganic cellulose residue. The XRD peaks were attributed to calcite $\left(\mathrm{CaCO}_{3}\right)$, rhombohedral crystal (PDF 5-586). However, the peaks were slightly more intense and defined for the grits residue than to lime mud due to the greater particle size of the grits (Table II) [27]. Therefore, the major compound present in the cellulose residues was calcium carbonate. During the heat treatment, the $\mathrm{CaCO}_{3}$ decomposed into $\mathrm{CaO}+\mathrm{CO}_{2}$.

In order to better identify the components of each residue, the precursor samples were thermally analyzed. The results are shown in Fig. 3. Fig. 3a shows that for DFS, there was a

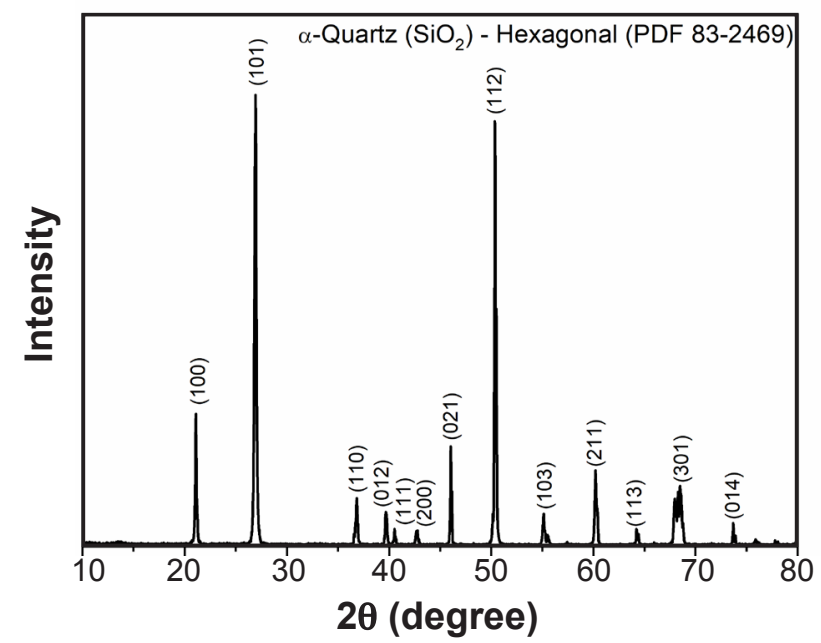

Figure 1: XRD pattern of DFS sample.

[Figura 1: Padrão de DRX da amostra de ADF.]

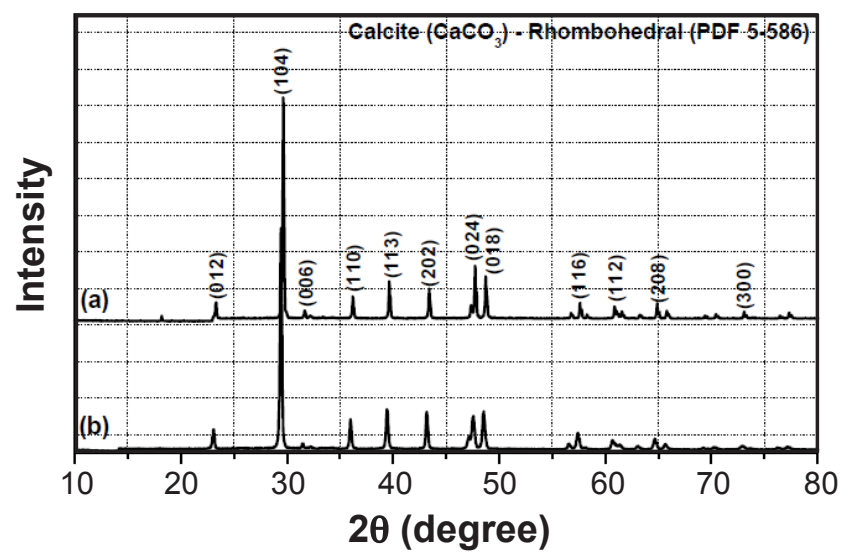

Figure 2: XRD patterns of precursor residues: a) grits; and b) lime mud.

[Figura 2: Padrões de DRX dos resíduos precursores: a) grits; e b) lama de cal.]

low mass loss of $1.93 \%$ below $230{ }^{\circ} \mathrm{C}$ due to adsorbed water, and $2.99 \%$ between 300 and $600{ }^{\circ} \mathrm{C}$ related to the degradation of the organic components, such as phenolic resin, used in the preparation of molds [28]. The exothermic process observed in the DSC (heat flow) curve between 200 and 570 ${ }^{\circ} \mathrm{C}$ confirmed the firing of organic materials (exothermic reaction). This mass loss was similar to the LOI (2.50\%). An endothermic reaction involving low energy absorption around $573{ }^{\circ} \mathrm{C}$ was also observed, and it is characteristic of silica polymorphic transition ( $\alpha$-quartz to $\beta$-quartz) [29]. Thermal analysis of cellulose residues (Fig. 3b) confirmed the similar chemical composition of the two precursors, as the thermogravimetric and calorimetric curves were similar for both samples. Around $48.6^{\circ} \mathrm{C}$, an endothermic reaction was observed for lime mud due to the moisture loss on the residue surface. The second endothermic reaction around $740{ }^{\circ} \mathrm{C}$ for the lime mud and grits was characteristic of the decomposition of $\mathrm{CaCO}_{3}$ [30-32], which composed the major crystalline phase of these samples evidenced by the X-ray diffractograms. The mass loss of the carbonate decomposition was around 38\%, which was in agreement with the LOI presented in Table III (40\% and 43\%). Lime mud presented a larger surface area and smaller particle size and, therefore, was more susceptible to water adsorption. The smaller particle size also explained the lower carbonate degradation temperature for this sample compared to grits.

Two glasses with distinct compositions (A and B, Table I) were produced from these precursors. Fig. 4 shows the obtained frits, which had a dark green color. This fact can be associated with the presence of iron oxide in the chemical composition of the precursors. The glasses were analyzed by XRF (Table IV), which confirmed the presence of iron oxide in the materials. Both glasses A and B presented similar amounts of $\mathrm{SiO}_{2}(69.4 \%$ and $70.1 \%), \mathrm{CaO}(18.3 \%$ and $17.6 \%), \mathrm{Al}_{2} \mathrm{O}_{3}(5.41 \%$ and $5.43 \%), \mathrm{Na}_{2} \mathrm{O}(5.02 \%$ and $5.21 \%$ ), and small concentrations of other oxides, which corroborate the stoichiometric calculation for the composition formulation.

XRD patterns of glass samples A and B (Fig. 5) revealed 

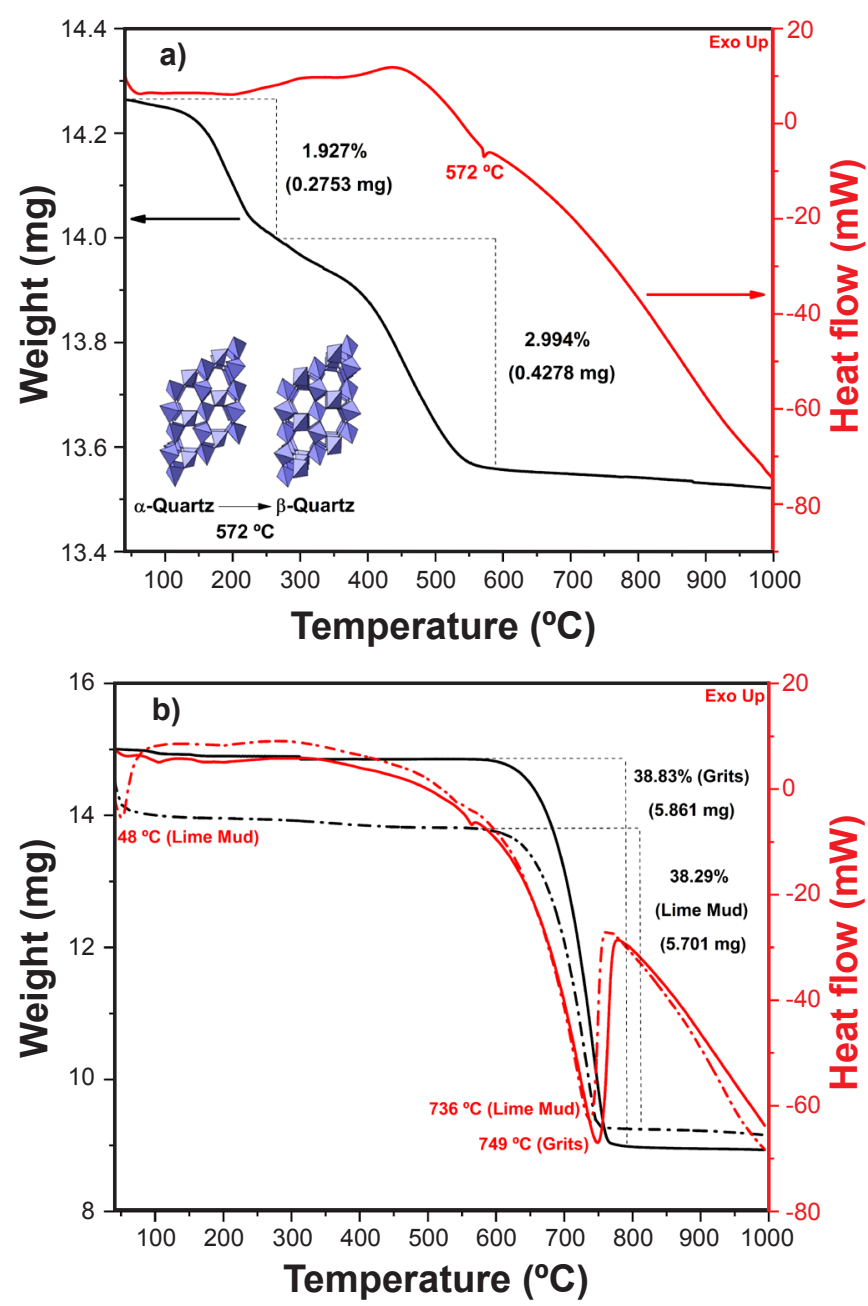

Figure 3: TGA and DSC curves of: a) DFS; and b) grits and lime mud. The inset in (a) shows the distortion of $\mathrm{SiO}_{2}$ tetrahedral clusters of the $\alpha$ and $\beta$-quartz.

[Figura 3: Curvas de TGA e DSC de: a) ADF; e b) grits e lama de cal. $O$ inserto em (a) mostra a distorção dos clusters tetraédricos da fases $\alpha$ e $\beta$ do quartzo.]

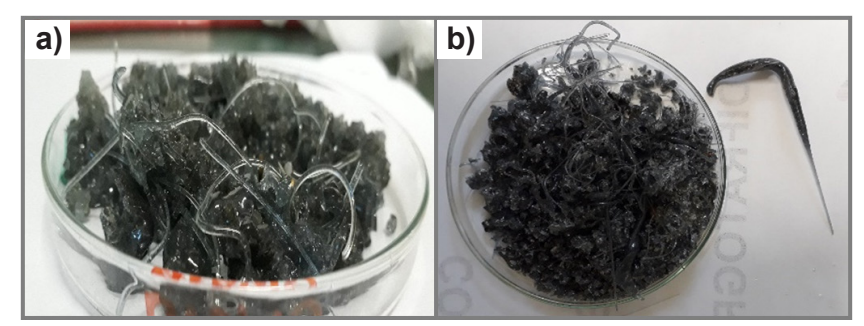

Figure 4: Images of frits (glasses) produced by mixing FDS and inorganic cellulose wastes: a) glass A (with grits); and b) glass B (with lime mud).

[Figura 4: Imagens das fritas (vidros) produzidas da mistura de ADF com os resíduos inorgânicos de celulose: a) vidro A (com grits); e b) vidro B (com lama de cal).]

a halo around $30^{\circ}(2 \theta)$, characteristic of vitreous (noncrystalline) materials, i.e., without long-range order within the atomic structure. Fig. 6 shows the thermal behavior (heat flow - DSC, and its derivative - DDSC) of each glass
Table IV - Results of semi-quantitative chemical analysis (wt\%) of glasses A and B by XRF spectroscopy.

Tabela IV - Resultados de análise química semiquantitativa (\% em massa) dos vidros A e B por espectroscopia de FRX.

\begin{tabular}{|c|c|c|}
\hline Oxide & Glass A & Glass B \\
\hline $\mathrm{SiO}_{2}$ & 69.40 & 70.10 \\
\hline $\mathrm{CaO}$ & 18.30 & 17.60 \\
\hline $\mathrm{Al}_{2} \mathrm{O}_{3}$ & 5.41 & 5.43 \\
\hline $\mathrm{Na}_{2} \mathrm{O}$ & 5.02 & 5.21 \\
\hline $\mathrm{Fe}_{2} \mathrm{O}_{3}$ & 0.65 & 0.68 \\
\hline $\mathrm{SO}_{3}$ & 0.62 & 0.59 \\
\hline $\mathrm{SrO}$ & 0.39 & 0.13 \\
\hline $\mathrm{TiO}_{2}$ & 0.06 & 0.07 \\
\hline $\mathrm{MnO}$ & 0.04 & 0.04 \\
\hline $\mathrm{K}_{2} \mathrm{O}$ & 0.03 & 0.06 \\
\hline $\mathrm{PdO}$ & 0.02 & 0.03 \\
\hline $\mathrm{ZrO}_{2}$ & 0.02 & 0.02 \\
\hline $\mathrm{CuO}$ & 0.01 & 0.02 \\
\hline $\mathrm{Ag}_{2} \mathrm{O}$ & 0.01 & 0.01 \\
\hline $\mathrm{ZnO}$ & 0.01 & 0.01 \\
\hline
\end{tabular}

sample. Fig. 6a shows the crystallization peaks of glass sample $\mathrm{A}$. The glass transition temperature $\left(\mathrm{T}_{\mathrm{g}}\right)$ was in the range of 674 to $701{ }^{\circ} \mathrm{C}$. Three crystallization peaks were observed, two broad peaks at 847 and $1032^{\circ} \mathrm{C}$ and a thinner intermediate peak at $921^{\circ} \mathrm{C}$, indicating the crystallization of a smaller number of phases. Similarly, Fig. $6 \mathrm{~b}$ shows the thermal behavior of glass sample $\mathrm{B}$. The $\mathrm{T}_{\mathrm{g}}$ was between 655 and $710{ }^{\circ} \mathrm{C}$ (verifiable only by heat flux derivative). Three crystallization peaks were observed at 870,929 , and $1148{ }^{\circ} \mathrm{C}$. The correct position of the crystallization peaks is of great importance because it delimits the thermal treatments necessary to obtain the respective glass-ceramic materials.

The pellets of glass samples ( 3 for each glass) were heated for $1 \mathrm{~h}$ at temperatures higher than those of crystallization

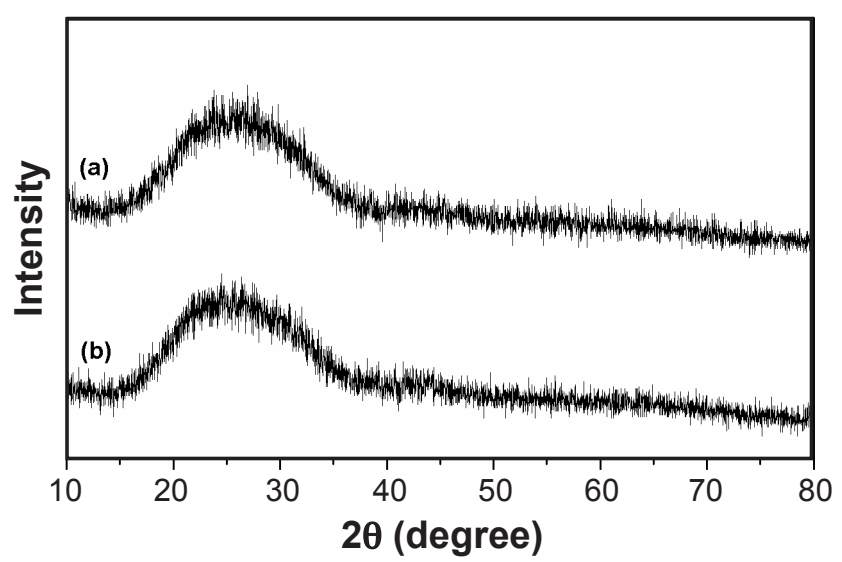

Figure 5: XRD patterns of glasses (frits): a) A; and b) B. [Figura 5: Padróes de DRX dos vidros (fritas): a) A; e b) B.] 

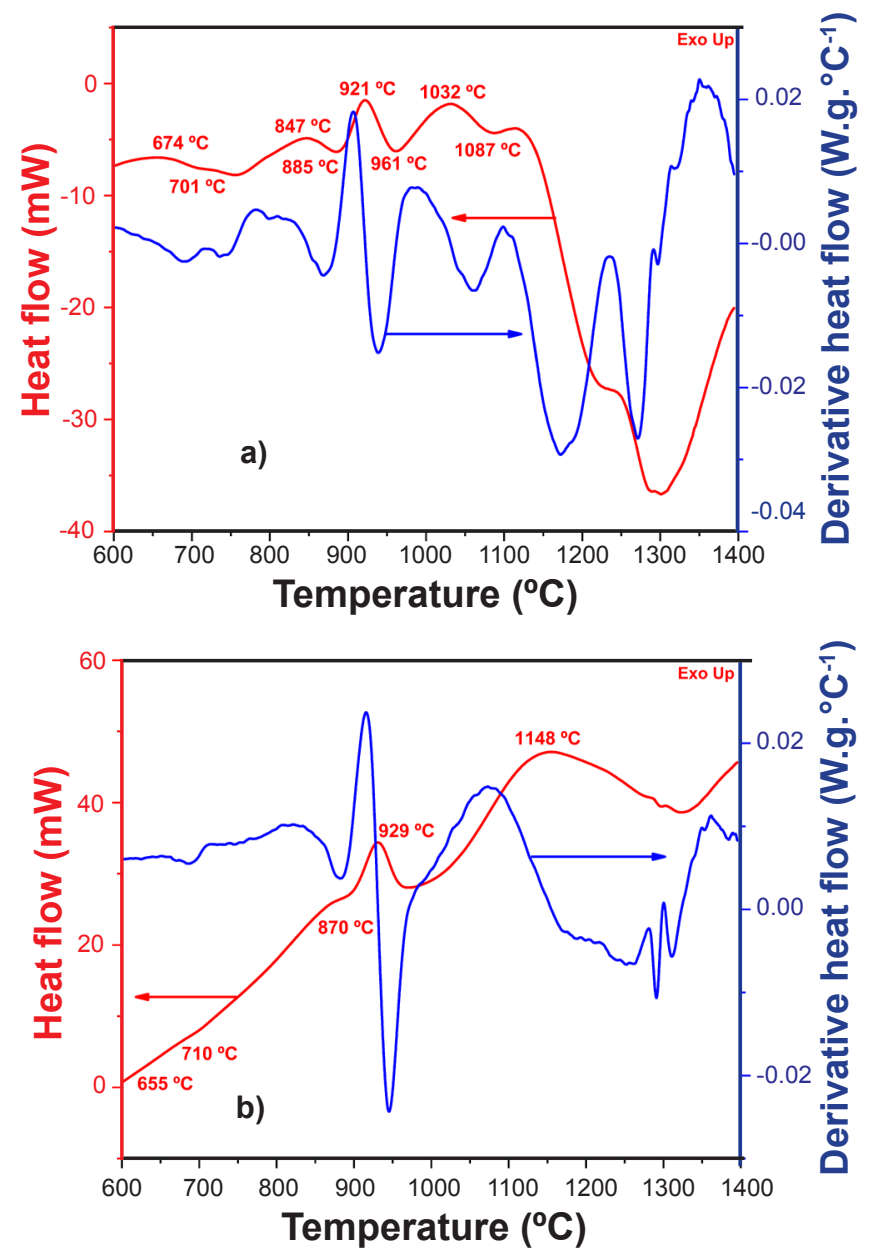

Figure 6: DSC and DDSC curves of: a) glass A; and b) glass B. [Figura 6: Curvas de DSC e DDSC de: a) vidro A; e b) vidro B.]

peaks. The images of glass A pellets before and after heat treatments at 885,961 , and $1090{ }^{\circ} \mathrm{C}$ are shown in Fig. 7. The change in pellet color was evident, which may be associated with both the crystal growth of the phases in the material and the variation in their concentrations, as demonstrated in the XRD patterns (Fig. 8). At the 3 temperatures, it was identified the presence of cristobalite $\left(\mathrm{SiO}_{2}\right)$ with tetragonal structure (PDF 82-512), $\alpha$-wollastonite $\left[\mathrm{Ca}_{3}\left(\mathrm{SiO}_{3}\right)_{3}\right]$ with monoclinic structure (PDF 89-6485), and $\beta$-wollastonite $\left(\mathrm{CaSiO}_{3}\right)$ with triclinic structure (PDF 3-626). Although the $\beta$ phase, the low-temperature modification, is the most frequently find and the $\alpha$ phase is the stable form above $1100{ }^{\circ} \mathrm{C}$, the results did not confirm this behavior, that is, both wollastonite phases were observed in the studied temperature range. This result may be associated with the influence of contaminants on precursors (residues). The irreversible transformation of $\beta$-wollastonite to $\alpha$-wollastonite only occurs above 1100 ${ }^{\circ} \mathrm{C}[33,34]$, which justifies the decrease in the intensity of $\beta$-wollastonite peaks at $1090{ }^{\circ} \mathrm{C}$ compared to the treated sample at $961^{\circ} \mathrm{C}$. Some silicates could go through metastable phases and, consequently, change the relative intensities of the stable phases. The identified phases by XRD analysis were in agreement with the frit composition, where high silica concentration resulted in the formation of cristobalite along with wollastonite. It was possible to identify a halo in the baseline around $30^{\circ}(2 \theta)$ in all samples, indicating the presence of the vitreous phase, i.e., confirming the formation of the glass-ceramic material.

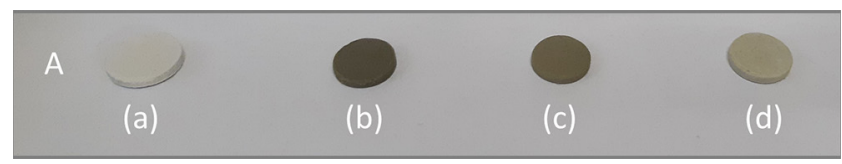

Figure 7: Images of glass A pellets before (a) and after thermal treatment for $1 \mathrm{~h}$ at: b) $885{ }^{\circ} \mathrm{C}$; c) $961{ }^{\circ} \mathrm{C}$; and d) $1090{ }^{\circ} \mathrm{C}$.

[Figura 7: Imagens das pastilhas do vidro A antes (a) e após tratamento térmico por $1 \mathrm{~h} \mathrm{a}$ : b) $885^{\circ} \mathrm{C}$; c) $961{ }^{\circ} \mathrm{C}$; e d) $1090{ }^{\circ} \mathrm{C}$.]

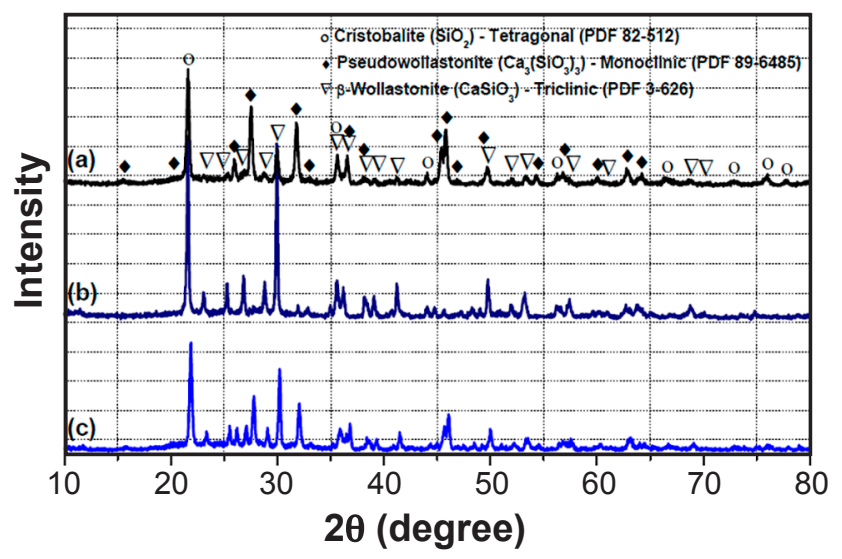

Figure 8: XRD patterns of glass-ceramic A after thermal treatment for $1 \mathrm{~h}$ at: a) $885^{\circ} \mathrm{C}$; b) $961^{\circ} \mathrm{C}$; and c) $1090^{\circ} \mathrm{C}$.

[Figura 8: Padrões de DRX do vitrocerâmco A após tratamento térmico por $1 \mathrm{~h} \mathrm{a:} \mathrm{a)} 885^{\circ} \mathrm{C}$; b) $961{ }^{\circ} \mathrm{C}$; e c) $1090^{\circ} \mathrm{C}$.]

The images of glass B pellets before and after heat treatments at 892,1007 , and $1180{ }^{\circ} \mathrm{C}$ are shown in Fig. 9 . The change in the pellet color was not so evident as for glass-ceramic A. The coloring of the glasses is usually associated with impurities, especially those represented by transition metal oxides, which favor the creation of point defects called color centers. The same happens, for example, when radiation interacts with the structure of the vitreous matrix, generating the same point defects, such as pairs of holes $\left(\mathrm{h}^{+}\right)$and electrons (e), which absorb light mainly in the UV and visible region of the electromagnetic spectrum, darkening the glass [35]. The colors of pellets produced here were light with the heat treatment, most likely due to the extinction of these color centers (reduction of point defects and grain boundaries by diffusion). The XRD patterns of the thermally treated samples (Fig. 10) revealed 3 phases as for the glass-ceramics A. An important difference was the reduction of $\beta$-wollastonite at $1180{ }^{\circ} \mathrm{C}$, which transformed into $\alpha$-wollastonite (Fig. 10c), the stable phase above 1100 ${ }^{\circ} \mathrm{C}$ [36]. Comparing the chemical composition of the two glasses (Table IV) with the $\mathrm{SiO}_{2}-\mathrm{Al}_{2} \mathrm{O}_{3}-\mathrm{CaO}$ ternary phase diagram [18], both compositions showed a great amount of silicon oxide located in the region of cristobalite/tridymite formation. These phases were formed at high temperatures, 
close to the melting temperature used in the glass preparation. Therefore, when the melted glass was cooled, cristobalite may have nucleated and remained in the cooled glass, lowering the silica concentration available for calcium silicate formation, which forms at lower temperatures than those phases of silicon oxide. The remaining silica reacted with calcium oxide to form metastable calcium silicates and wollastonite, among its different structures ( $\alpha$ and $\beta$-wollastonite) during the thermal treatment. This process resulted in a glass-ceramic material composed of 3 distinct crystalline phases.

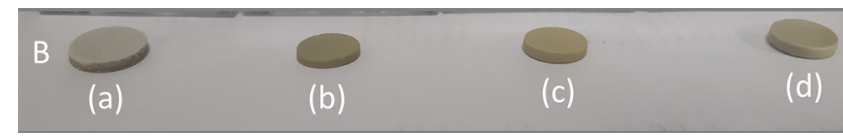

Figure 9: Images of glass B pellets before (a) and after thermal treatment for $1 \mathrm{~h}$ at: b) $892^{\circ} \mathrm{C}$; c) $1007{ }^{\circ} \mathrm{C}$; and d) $1180{ }^{\circ} \mathrm{C}$.

[Figura 9: Imagens das pastilhas do vidro $B$ antes (a) e após tratamento térmico por $1 \mathrm{ha:b} 892^{\circ} \mathrm{C}$; c) $1007{ }^{\circ} \mathrm{C}$; e d) $\left.1180{ }^{\circ} \mathrm{C}.\right]$

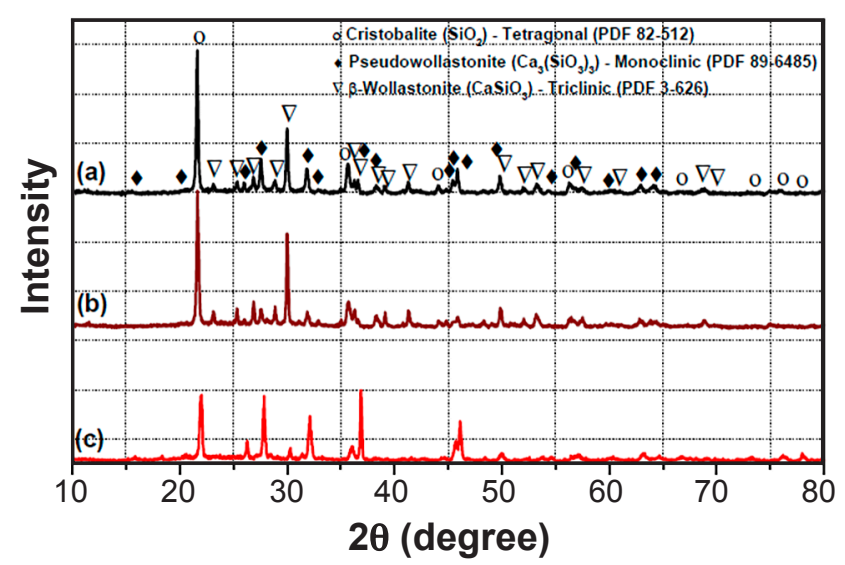

Figure 10: XRD patterns of glass-ceramic B after thermal treatment for $1 \mathrm{~h}$ at: a) $892^{\circ} \mathrm{C}$; b) $1007^{\circ} \mathrm{C}$; and c) $1180{ }^{\circ} \mathrm{C}$.

[Figura 10: Padrões de DRX do vitrocerâmico $\mathrm{B}$ após tratamento térmico por $1 \mathrm{ha}$ : a) $892^{\circ} \mathrm{C}$; b) $1007^{\circ} \mathrm{C}$; e c) $1180^{\circ} \mathrm{C}$.]

The results of water absorption (WA) and apparent porosity (AP) for glass-ceramics A and B ranged as WA from 0.26 to $0.88 \mathrm{wt} \%$ and AP from 0.66 to 1.77 vol\% (Table V). The results showed that the higher the porosity, the higher was the water absorption, as expected. Water absorption $\leq 0.5 \%$ classifies this glass-ceramic material in group BIa of Brazilian standard for porcelain tiles. With the exception of one sample with $0.88 \mathrm{wt} \%$ of WA, all glass-ceramic pellets had water absorption smaller than $0.5 \%$. However, no correlation could be established between water absorption and apparent porosity of the materials with the increase of sintering temperature, probably due to the complexity of the microstructure of glass-ceramic materials. The apparent specific gravity values were between 2.00 and $2.50 \mathrm{~g} / \mathrm{cm}^{3}$. As the theoretical density of wollastonite is $2.90 \mathrm{~g} / \mathrm{cm}^{3}$ [37] and for cristobalite is $2.33 \mathrm{~g} / \mathrm{cm}^{3}$, the combination of these phases generates materials with density between these values. Zhang et al. [36] and Almasri et al. [37] have reported the increase of wollastonite density with the sintering temperature from 700 to $1100{ }^{\circ} \mathrm{C}$. The results obtained in this study were smaller than those of wollastonite and cristobalite, probably due to the particular microstructure of different crystalline phases and the amorphous portion of the material. The sintering process adopted for the densification of glass-ceramic pellets may have been the main factor for the reduction of the densities obtained in relation to those in the literature. The short sintering time $(1 \mathrm{~h})$ may have been the determining factor in this reduction in density and consequent increase in porosity.

\section{CONCLUSIONS}

This study showed that the precursor materials of discarded foundry sand (DFS) and cellulose residues (grits and lime mud) can be used as raw materials in the manufacture of glassy and glass-ceramic materials. The X-ray diffraction patterns showed that cristobalite, $\alpha$-wollastonite, and $\beta$-wollastonite were the major crystalline phases in the glass-ceramic materials. These phases were obtained at lower temperatures $\left(\geq 885^{\circ} \mathrm{C}\right)$ than those usually mentioned in the literature. The glass-ceramic pellets showed low water absorption and apparent porosity, which can be classified as material in group BIa of Brazilian standard for porcelain tiles. Therefore, it is possible to produce cheap glass-ceramic materials, for example, for tiles, by recycling precursors such as DFS, grits, and lime mud.

\section{REFERENCES}

[1] Assoc. Bras. Fund., Fund. Matér.-Primas 12, 113 (2009) 84.

[2] M.C. Zenetti, S. Fiore, C. Clerici, J. Solid Waste Tech. Manag. 30 (2004) 28.

[3] A.R. Fagundes, C.R. Vaz, I.L. Oliveira, J.L. Kovaleski, Gest. Prod. Oper. Sist. 5, 2 (2010) 27.

Table V - Water absorption, apparent porosity, and apparent specific gravity for glass-ceramics A and B. [Tabela V - Absorção de água, porosidade aparente e massa específica aparente das vitrocerâmicas A e B.]

\begin{tabular}{|c|c|c|c|c|c|c|}
\hline \multirow[b]{2}{*}{ Glass-ceramic } & \multicolumn{2}{|c|}{ Water absorption (wt\%) } & \multicolumn{2}{|c|}{ Apparent porosity (vol\%) } & \multicolumn{2}{|c|}{ Apparent specific gravity $\left(\mathrm{g} / \mathrm{cm}^{3}\right)$} \\
\hline & $\begin{array}{l}\text { Minimum } \\
\text { value }\end{array}$ & $\begin{array}{c}\text { Maximum } \\
\text { value }\end{array}$ & $\begin{array}{l}\text { Minimum } \\
\text { value }\end{array}$ & $\begin{array}{c}\text { Maximum } \\
\text { value }\end{array}$ & $\begin{array}{l}\text { Minimum } \\
\text { value }\end{array}$ & $\begin{array}{l}\text { Maximum } \\
\text { value }\end{array}$ \\
\hline A & 0.26 & 0.88 & 0.66 & 1.77 & 2.00 & 2.50 \\
\hline $\mathrm{B}$ & 0.33 & 0.40 & 0.71 & 0.97 & 2.08 & 2.49 \\
\hline
\end{tabular}


[4] Celulose Nipo-Bras., "Relatório de sustentabilidade 2017", Brazil, www.cenibra.com.br (2017).

[5] M.J.C. Sponchiado, J.H. Silva, O. Maluf, M.R.M. Jabur, Rev. Academus 6, 1 (2018) 1.

[6] D.R. Torres, R.C.O. Romano, R.G. Pileggi, Cerâmica 63, 368 (2017) 508.

[7] M. Pasetto, N. Baldo, Constr. Build. Mater. 25, 8 (2011) 3458.

[8] A. Arulrajah, A. Mohammadinia, A. D'Amico, S. Hopibulsuk, Constr. Build. Mater. 145 (2017) 218.

[9] V. Mymrin, K.P. Alekseev, O.M. Fortini, R.E. Catai, A. Nagalli, J.L. Rissardi, A. Molinetti, D.E. Pedroso, R.L.S. Izzo, J. Clean. Prod. 145 (2017) 367.

[10] V. Mymrin, K.P. Alekseev, R.E. Catai, A. Nagalli, Y.K. Aibuldinov, N.S. Bekturganov, J.L. Rose, R.L.S. Izzo, J. Environ. Chem. Eng. 4 (2016) 753.

[11] V. Mymrin, A. Nagalli, R.E. Catai, R.L.S. Izzo, J. Rose, C.A. Romano, J. Clean. Prod. 147 (2016) 888.

[12] R. Alonso-Santurde, A. Coz, J.R. Viguri, A. Andrés, Constr. Build. Mater. 27 (2012) 87.

[13] A.C. Martin, O.K. Ueno, M.V. Folgueras, in Proc. $22^{\circ}$ Congr. Bras. Eng. Ciên. Mater., Natal (2016) 2582.

[14] S. Chegatti, S.R. Soares, M.K. Gonçalves, M. Buras, R.M. Silveira, Tecnol. Metal. Mater. Min. 10, 2 (2013) 146.

[15] R.Q. Santos, N.S. Soares, M.I.F. Ferraz, E.P. Souza, Rev. Espacios 37, 8 (2016) 4.

[16] C.J.C. Bacha, "Markets of forest products in 2017 and 2018", Center Adv. Stud. Appl. Econ., Piracicaba, www. cepea.esalq.usp.br (2018).

[17] A.F.J. Bellote, H.D. Silva, C.A. Ferreira, G.C. Andrade, Rev. Madeira 77 (2003).

[18] W. Höland, G. Beall, Glass-ceramic technology, Am. Ceram. Soc., Ohio (2002) 448.

[19] ABNT NBR 10004, "Resíduos sólidos: classificação", Assoc. Bras. Norm. Técn., Rio Janeiro (2004).

[20] W. Chengyu, T. Ying, Glass Technol. 24, 5 (1983) 278.

[21] H. Li, C.S. Ray, R. Stranhan, R. Weber, Y.Z. Yue (Eds.), "Melt chemistry, relaxation, and solidification kinetics of glasses", Am. Ceram. Soc., Indiana (2003) 170.

[22] M. Akerman, "Introdução ao vidro e sua produção", Escola Vidro, www.certev.ufscar.br (2013).

[23] A.K.R. Souza, A.P. Langaro, J.R. Silva, F.B. Costa, K. Yukimitu, J.C.S. Moraes, A.O. Nunes, L.H.C. Andrade, S.M. Lima, J. Alloys Compd. 781 (2019) 1119.

[24] R.P. Freitas, V.S. Felix, M.O. Pereira, R.S. Santos, A.L. Oliveira, E.A.S. Gonçalves, D.S. Ferreira, A.R. Pimenta, L.O. Pereira, M.J. Anjos, Microchem. J. 149 (2019) 104020. [25] B. Lin, X.M. Jiang, S.P. Li, Z.C. Cao, J. Manuf. Process. 46, 1 (2019) 279.

[26] N. Marinoni, V. Diella, G. Confalonieri, A. Pavese, F. Francescon, Ceram. Int. 43, 14 (2017) 10895.

[27] C.J. Papini, W.K. Yoshito, D. Gouvêa, R.M.L. Neto, Mater. Sci. Forum 498 (2005) 73.

[28] H.M. Basar, N.D. Aksoy, Constr. Build. Mater. 35 (2012) 508.

[29] A.H.A. Pereira, D.Y. Miyaji, M.D. Cabrelon, J. Medeiros, J.A. Rodrigues, Cerâmica 60, 355 (2014) 449.

[30] G. Narsimhan, Chem. Eng. Sci. 16 (1961) 7.

[31] S.F.S. Mohamad, S. Mohamad, Z. Jeemat, J. Eng. Appl. Sci. 11, 16 (2016) 9917.

[32] S.R. Teixeira, R.S. Magalhães, A. Arenales, A.E. Souza, M. Romero, J.M. Rincón, J. Environ. Manage. 134 (2014) 15.

[33] R. Shamsudin, F.A.A. Azam, M.A.A. Hamid, H. Ismail, Materials 10, 10 (2017) 1188.

[34] K.S. Park, H.S. Ryu, J.H. Seo, K.S. Hong, H. Kim, J.H. Lee, D.H. Lee, B.S. Chang, C.K. Lee, Key Eng. Mater. 254256 (2004) 151.

[35] B. Karmakar, Functional glasses and glass-ceramics: processing, properties, and applications, Elsevier, Oxford (2017) 108.

[36] W. Zhang, H. Liu, Ceram. Int. 39, 2 (2013) 1943.

[37] K.A. Almasri, H.A.A. Sidek, K.A. Matori, M.H.M. Zaid, Results Phys. 7 (2017) 2242.

(Rec.13/12/2019, Rev.09/03/2020,08/04/2020,09/05/2020, 18/05/2020, Ac. 21/05/2020) 